Pregledni znanstveni rad

DOI: $10.17234 /$ Croatica.42.17

UDK: 811.163.42(091)

811.163.42’36Veber Tkalčević, A.

Primljen: 20. XI. 2017.

Prihvaćen: 9. I. 2018.

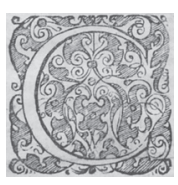

\title{
VEBEROVA GRAMATIČKA PROMIŠLJANJA O HRVATSKOM JEZIKU U LATINSKOI SLOVNICI ZA NIŽU GIMNAZIJU (1853)
}

\author{
Željka Brlobaš \\ Institut za hrvatski jezik i jezikoslovlje \\ Ulica Republike Austrije 16, 10000 Zagreb \\ zbrlobas@ihjj.hr
}

U Latinskoj slovnici za nižu gimnaziju (Beč, 1853) Adolfa Vebera Tkalčevića na pojedinim mjestima opisa usporedno se navode i gramatička pravila svojstvena hrvatskomu jeziku. U radu se analiziraju tri osnovna modela gramatičkoga opisa kojima se u polaznom tekstu latinske školske gramatike pokazuju Veberova gramatička promišljanja o hrvatskom jeziku. Prvi je model usporednoga opisa sličnosti ili razlika pojedinih gramatičkih pravila u oba jezika. Drugi je model onaj u kojem Veber raspravlja o gramatičkom problemu svojstvenom hrvatskom jeziku. Prema trećemu modelu uz gotovo svako navedeno gramatičko pravilo latinskoga jezika Veber objašnjava gramatičko pravilo u hrvatskom jeziku. U kontekstu povijesti hrvatskih gramatika analizirani svojevrsni gramatički metakomentari o hrvatskom jeziku na primjeru opisa latinskoga jezika pokazuju Veberova objašnjenja pojedinih kategorijalnih obilježja gramatike hrvatskoga jezika."

Ključne riječi: Latinska slovnica za nižu gimnaziju (1853), Adolfo Veber Tkalčević, gramatička pravila hrvatskoga jezika

* Poslije svih dosad objavljenih znanstvenih radova prof. dr. Ive Pranjkovića o hrvatskom jezikoslovcu A. Veberu Tkalčeviću ovom skromnom analizom zadane teme zahvaljujem poštovanomu i cijenjenomu Profesoru za sve znanstvene prinose proučavanju povijesti gramatika hrvatskoga jezika i poticaje za moja jezičnopovijesna gramatička istraživanja. 


\section{UVOD}

U opusu jednoga od najvrsnijih gramatičara 19. stoljeća, A. V. Tkalčevića, osim gramatika hrvatskoga jezika nalaze se i izdanja latinske slovnice namijenjena školskoj uporabi. Naime 1853. godine, prije Skladnje ilirskoga jezika za niže gimnazije (1859), objavljena je u Beču Veberova Latinska slovnica za nižu gimnaziju, školska gramatika latinskoga jezika, a ponovljeno izdanje navedene gramatike objavljeno je također u Beču 1865. godine. Pišući o A. Veberu Tkalčeviću, Ivo Pranjković (1993: 18) ističe da je Veber slovnicu "napisao za četiri mjeseca neumorna rada 'čuvajuć se u to vrijeme svih mogućih zabavah' (Djela I: 17)”, kako to navodi i sam autor u tekstu o svojem životopisu (Veber 1885: 17). Nakon povratka sa školovanja u Beču Veber je 1852. imenovan učiteljem latinskoga jezika zagrebačke gimnazije, a iste je godine "s uvedbom hrvatskoga jezika u gimnazije nastala velika potreba knjigah” (Veber 1885: 17), stoga je, u kontekstu latinskih školskih priručnika, uz Latinsku slovnicu bio zadužen i za sastavljanje Latinske čitanke za II. razred po Mavri Schinagelu (1853).

U kontekstu propitivanja nastanka gramatika latinskoga jezika u 19 . st. Šime Demo smješta Veberovu Latinsku slovnicu između Grigelyeve gramatike s početka stoljeća koja joj je prethodila i gramatike Ivana Pavca (Latinska slovnica, Zagreb, 1881), zaključujući da je "bila silno važan korak u osuvremenjivanju nastave gramatike, a dakako i u promicanju narodnoga jezika u nastavi" (Demo 2007: 41).

S kroatističkoga stajališta, i to u kontekstu povijesti hrvatskoga jezikoslovlja, poglavito povijesti hrvatskih gramatika, Veberova Latinska slovnica za nižu gimnaziju (1853) važna je po tome što je metajezik gramatike u potpunosti hrvatski (osim latinskih oprimjerenja u paradigmama ili u gramatičkom tekstu), što je gramatičko nazivlje u gramatici hrvatsko (uključujući i Veberove definicije gramatičkih kategorija) i što Veber u opisu latinskoga jezika na određenim mjestima usporedno navodi i gramatička pravila svojstvena hrvatskomu jeziku. Time je metodološki i didaktički nastojao približiti istodobno učenje latinskoga i hrvatskoga jezika, u čemu mu je svojevrsni prethodnik i Antun Mažuranić u Temeljima ilirskoga i latinskoga jezika za početnike (1839). Godine 1872. u Zagrebu Veber objavljuje Slovnicu latinsku za male gimnazije (prema naslovnici drugo popravljeno izdanje). ${ }^{1}$

Treće izdanje gramatike istoga naslova objavljeno je 1877. god. U odnosu na promijenjen naslov i određene izmjene u tekstu može se smatrati svojevrsnim drugim izdanjem Latinske slovnice za nižu gimnaziju. 
Gramatika je pisana hrvatskim jezikom, prerađena je i sadržajno proširena u odnosu na Slovnicu iz 1853. (u posebnom je poglavlju dodano glasoslovje), a gramatička su pravila o hrvatskom jeziku u tekstu latinske gramatike znatno reducirana. $^{2}$

Pišući 1869. god., nakon izdanja 1865, kritički prikaz Latinske slovnice za nižu gimnaziju u Izvješćc gimnazije varaždinske, Franjo Pongračić ${ }^{3}$ naglašava da je Veberova "slovnica najvećoj nuždi naših gimnazijah doskočila te da je s njom g. Veber našoj mladeži mnogo olakšao učenje latinskoga jezika" (Pongračić 1869: 4). Međutim Pongračić je u ocjeni, pojedinačno usmjerenoj na prikaz pojedinosti uporabe latinskih glagolskih vremena u sintaktičkom dijelu slovnice, istaknuo četiri načelna prigovora, od kojih u jednom od njih ističe sljedeće: "Pregledu pravilah škodljivo je osobito to, da g. Veber stavljajuć pravila za latinski jezik, ujedno obširno razvija pravila za hèrvatski jezik" (Pongračić 1869: 4). ${ }^{4}$

Cilj je u ovom radu analizirati upravo spomenuta Veberova gramatička pravila o hrvatskom jeziku supostavno navedena u tekstu latinske gramatike i utvrditi o kojim je pravilima riječ, u kojim su odjeljcima navedena, koja im je izrazna struktura i koju imaju ulogu u polaznom gramatičkom tekstu. U radu se propituju tri osnovna modela opisa prema kojima je moguće svrstati Veberova gramatička promišljanja o hrvatskom jeziku, koja možemo smatrati svojevrsnim autorovim gramatičkim metakomentarima o hrvatskom jeziku na primjeru opisa latinskoga jezika.

$\mathrm{U}$ radu se koristi deskriptivna metoda s ciljem opisa zadane teme $\mathrm{u}$ polaznome tekstu latinske gramatike pisane hrvatskim jezikom, a djelomično se $u$ analizi primjenjuje i metoda usporedbe pojedinih gramatičkih pravila hrvatskoga jezika u odnosu na opis u izdanju iz 1872. godine, zatim u gra-

2 Kritički prikaz navedenoga izdanja gramatike napisao je Jovan Turoman (usp. Turoman 1875), što podrobnije, između ostaloga, analizira i Demo (2007). Veber je odgovorio na Turomanov sud o slovnici u članku Kako treba pisati latinske slovnice za gimnazije (usp. Veber 1889).

3 Gimnazijski profesor (rođen je 1834. u Prelogu, a umro 1899. u Varaždinu) latinskoga i grčkoga jezika (od 1858), a povremeno i hrvatskoga, dugi je niz godina obavljao i dužnost ravnatelja gimnazije u Varaždinu.

4 Navedeni prigovor dalje objašnjava: "To je za pèrvi početak dobro bilo, ali sada, kada učenici imadu posebnu skladnju za hèrvatski jezik, nečini mi se potrebno, barem ne u onom obsegu, da su pravila za hèrvatski jezik višeputah obširnija nego za latinski. To kod učenja veoma smeta, jer učenik měša pravilo za hèrvatski jezik s pravilom za latinski jezik. Stoga bi valjalo ta pravila izostaviti, pak se samo na toliko obzirati na hèrvatski jezik, na koliko je to od potrebe za latinski jezik, n. p. da se kaže, kakovimi izrekami prevadjamo accusativus cum infinitivo, ut, ne quin i t. d." (isto). 
matikama hrvatskoga jezika u Vebera (Skladnja 1859, Slovnica hèrvatska 1871) i A. Mažuranića.

\section{ANALIZA OPISA (METAKOMENTARA) GRAMATIČKIH PRAVILA HRVATSKOGA JEZIKA}

Veberova latinska slovnica iz 1853. godine sadržajno ima dva temeljna dijela, morfološki (rěčoslovlje) - strukturiran prema opisu vrsta riječi u latinskom - i sintaktički (skladnja) u kojem je uz sintaksu padeža i poraba glagolskih vremena i načina te sintaksa složene rečenice "koje nijedna naša dotadašnja latinska gramatika nije obrađivala, a i u gramatikama su hrvatskoga bile novost" (Demo 2007: 41). ${ }^{5}$

U predgovoru Veber ističe da su mu uzori bila djela Ferdinanda Schultza, Karla Eduarda Putschea i predavanja Karla Grysara, a pritom objašnjava i svoj metodološki postupak utemeljen na kontrastivnom pristupu: "Svakako sam nastojao, da pravila od oba jezika što jasnije razvijem, nebi li se znanje krasnoga latinskoga jezika u našu domovinu povratilo; što ako se sbude, biti će najveća nagrada moga rada i truda" (predgovor, IV).

\subsection{Izrazna razina opisa gramatičkih pravila hrvatskoga jezika}

Pišući osnovni gramatički tekst o latinskom jeziku, Veber usporedbe s hrvatskim jezikom uvodi određenim izrazima. Izrazi kojima u osnovnom gramatičkom tekstu o pravilima latinskoga jezika Veber uvodi pravilo o hrvatskom jezike mogu se svrstati u nekoliko temeljnih skupina, npr.:

1) oni u kojima se uopćeno navodi postojanje gramatičke činjenice u hrvatskom jeziku, npr. "u nas" (40), " "u nas stoji uvěk" (185), "u našem se jeziku" (196), "naški” (180), "naški se prevode" (47)

2) oni kojima se objašnjava istost gramatičke činjenice i u hrvatskom jeziku u odnosu na latinski, npr.: "[x] je u latinskom kano i u našem jeziku"

5 U sadržajnom dijelu dodatka gramatike poglavlja su O slovkoměru, O stihotvorstvu, Rimski kalendar, Rimska vaga, novci, měre, Kratice i Kazalo.

6 Označuje se samo jedna stranica iz izvornika s navedenim izrazom, a znakovima [x] i [y] označuju se ispušteni dijelovi gramatičkoga opisa u ovdje uopćenom izrazu. Ostali citati iz Veberove Latinske slovnice (1853) navode se samo brojkom stranice (bez godine izdavanja). 
(2), “to valja i u našem jeziku" (181), "i u našem i u latinskom jeziku” (175), "i u latinskom i u našem jeziku" (180), "i u nas i u Latinah" (211), "u slučaju [x] se postupa kano u latinskom jeziku" (177), "u ovom se slučaju naš jezik slaže s latinskim, samo što [x]" (196)

3) oni kojima se ističe različitost u hrvatskom u odnosu na latinski, npr.: "naški město [x] postavlja se [y]" (182), "kad je u latinskom [x] u nas je uvěk [y]" (175), "Latini metju/uzimaju [x], gdě mi uzimamo/metjemo/dodajemo [y]", "velika je razlika medju našim i latinskim jezikom" (177), "mi u svom jeziku pravimo razliku medju [x]" (194), "[x] u latinskom jeziku češtje biva nego u našem" (152)

4) objašnjenje koje se odnosi na cjelinu gramatičkoga opisa, npr.: "Što nije ovdě o našem jeziku posebice napomenuto, o tom valjaju ista pravila, koja i u latinskom jeziku" (168).

Tomu valja dodati i poredak uspoređenih gramatičkih opisa. Dok najčešće u usporedbama Veber prvo opisuje stanje u latinskom, a onda navodi objašnjenje za hrvatski, rjeđe se nailazi i na obrnut postupak, najprije počinje s hrvatskim obilježjem gramatičke pojave, npr. "Zaime tretje osobe izrazuje se u nas povratnim zaimenom, sebe, sebi, se; svoj, svoja svoje kad se proteže na subjekt iste izreke", a zatim nastavlja s latinskim: "U latinskom jeziku valjaju o tom ova pravila [...]" (227). Jednako i u primjeru: "U nas se običava pobliže označenje koje stvari izraziti sa: i to, latinski sa: et is; et is quidem, atque is, niječno: nec is" (231).

\subsection{Modeli opisa gramatičkih pravila hrvatskoga jezika}

Usporedan opis gramatičkih pravila hrvatskoga i latinskoga jezika u Veberovoj je slovnici i u morfološkom i u sintaktičkom dijelu, no različito zastupljen, tako da svi opisi gramatičkih činjenica latinskoga jezika nisu potkrijepljeni i onima u hrvatskom jeziku. Stoga nalazimo nekoliko modela gramatičkoga opisa koji pokazuju Veberova promišljanja o hrvatskom jeziku, tj. usporedno navođenje gramatičkih pravila hrvatskoga jezika u temeljnom gramatičkom opisu latinskoga jezika.

\subsubsection{Prvi model opisa}

U prvom se modelu usporednoga opisa ističu sličnosti/razlike između pojedinih gramatičkih kategorija ili gramatičkih pravila u oba jezika. Navedeni se 
model (oprimjeren samo pojedinim pripadajućim primjerima) ne odnosi na usporedan opis svake gramatičke činjenice u latinskom i hrvatskom jeziku, već u morfološkom i sintaktičkom dijelu ovisi o Veberovu izboru kojim će gramatičkim kategorijama latinskoga jezika supostaviti opis tih istih kategorija u hrvatskom, npr.:

(1) Samostavnici su u latinskom kano i u našem jeziku trostrukoga spola. (2)

(2) Višebrojnici se děle na one, koji se i na naš jezik prevode višebrojem, i na one, koji jednobrojem. (26)

(3) U latinskom se jeziku razlikuju kano i u našem tri stupnja pridavnikah, naime: pèrvi, drugi i tretji. (39)

(4) Dělni brojnici rabe, kad se pita: po koliko? [...] u nas se pred glavne metje: po. (54)

(5) $[\ldots]$ inače neimaju zaimena tretje osobe, već město njega uzimaju pokazna zaimena: is, ille; u nas je razlika izmedju: on, njega itd. i on, onoga itd. (61)

(6) Latini metju često višebroj, gdě mi uzimamo jednobroj, naime: 1 . Město ego veli se često nos, město meus, noster (no nikad vos město tu), n. p. [...] ja, konzul, neradim kako bi valjalo [...] 2. Latini, kad hoće da naznače razne vèrsti abstraktnih pojmovah, uzimaju rěč u višebroju, gdě mi metjemo ili jednobroj ili dodajemo rěč: vèrsti [...]. 3. Kad se latinski pridavnik ili zaime proteže na više neimenovanih stvarih, metje se u višebroj srědnjega spola; u nas je uvěk jednobroj [...] 4. Za životinje uzimaju Latini jednobroj gdě nam rabi višebroj [...] Isto tako pověstnikom rabi: miles, eques, pedes, što nam: vojaci, konjanici, pěšaci. (174-175).

(7) Imena gradovah i manjih otokah, kad se naznačuje kretanje onamo na pitanje kamo? postavljaju se u akuzativ bez predloga; naški s predlogom u ili na. - Na pitanje odakle? postavljaju se imena u ablativ bez predloga; naški u genitiv s predlogom iz. - Kad se naznačuje mirovanje, na pitanje gdě? metju se jednobrojnici pèrvoga i drugoga sklanjanja u genitiv, višebrojnici pako i sva imena tretjega sklanjanja u ablativ bez predloga; naški sva u prepozicional s predlogom u. (184)

(8) Pridavnički brojnici nezahtěvaju genitiva, kad naznačuju upravo onoliko stvarih koliko ih ima u cělosti; u nas se i u ovom slučaju uzima genitiv, n. p. Caesar auctoritatem suam legionibus, quas undecim habebat, defendit; kojih je jedanaest imao. [...] Nostri (naših) circiter septuaginta ceciderunt. (201)

(9) Kad se naznačuje družtvo, metje se uvěk i u nas i u Latinah predlog cum i sa (211)

(10) 2. Laborare ex capite itd. prevodi se naški: boli me glava. itd. (212)

(11) Amo ide i ipse, kojemu se i u našem i latinskom jeziku měnja značenje, kad ostaje u nominativu ili kad se slaže sa zaimenom; se ipse interfecit, znači: ubio je sam sebe (to jest: drugi ga nije ubio); a se ipsum interfecit, ubio je sama sebe (ne drugoga). (224) 
(12) U nas se kadšto već u glavnoj izreci navede subjekt ovisne predlogom za ili o, n. p. Za Cicerona govore, da je bio slavoljuban; u latinskom valja ovaj subjekt metnuti u akuzativ, a u ovisnoj izreci nevalja ponavljati zaimena [...]. (292)

(13) U izkvarenom načinu pisanja uzimamo mi: bez da, što je na němačku; u nas se ovakov izraz prevodi ili gerundijem ili sa: da ne; Latini pako, ako je glavna izreka jestna, prevode ga ili dioničnom izrekom ili ablativom absolutnim sa non, ili gdě toga neima sa: ut non, kadšto sa neque. (314)

Na temelju odabranih primjera, i ostalih koje Veber navodi u gramatici, gramatička pravila o hrvatskom jeziku protežu se morfološkim i sintaktičkim dijelom gramatike, ovisno o Veberovu izboru onih gramatičkih činjenica u latinskom kojima će supostaviti hrvatsko gramatičko pravilo koje se odnosi na:

a) gramatičku kategoriju svojstvenu obama jezicima, npr. (1), (2), (3)

b) prijevod ili objašnjenje značenja pojedinih primjera, npr. (10), (11)

c) na razlike između pojedinih pravila u oba jezika (što se može potkrijepiti najvećim brojem primjera).

Od navedenih primjera u izdanju gramatike 1872. godine pojedina gramatička pravila ne sadrže usporedbe s hrvatskim jezikom, npr. (1): "Samostavnici su trostrukoga spola: mužkoga, ženskoga i srednjega” (Veber 1872: 7), dok je u pojedinim usporedba ostala, npr. (3): "U latinskom se jeziku razlikuju kano i u našem tri stupnja pridavnikah, naime: pozitiv, komparativ i superlativ" (Veber 1872: 29).

\subsubsection{Drugi model opisa}

Prema drugomu modelu Veber ne samo da na pojedinim mjestima supostavlja opisu latinskoga usporedno objašnjenje za hrvatski nego i raspravlja ili komentira o gramatičkom problemu svojstvenomu hrvatskom jeziku. Taj model s pripadajućim primjerima pokazuje Veberove stavove prema pojedinim objašnjenjima gramatičkih činjenica u hrvatskom jeziku i potvrđuje Vebera kao autora gramatika hrvatskoga jezika koje su uslijedile poslije latinske gramatike.

Tako u opisu latinskih brojeva kao vrste riječi (smatra ih pridjevima i dijeli ih na glavne, redne, dělne, množne i razměrne) u dijelu o glavnim

\footnotetext{
Navedeni dio osnovnoga teksta gramatike sadržajno je oblikovan i u Skladnji ilirskoga jezika u poglavlju o participu: "Pazke. 1. U izkvarenom se načinu pisanja uzima: bez $d a$, što je na němačku; město toga metje se ili prislov g. ili izreka sa da ne; n. p. Otidjemo svaki u svoju sobu spavat, neprogovorivši jedan s drugim ni rěči, ili: da neprogovori, nipošto bez da progovori" (Veber 1859: 142).
} 
brojevima i njihovu sklanjanju u latinskom ističe sljedeće što je svojstveno hrvatskomu: "U nas su do pet pridavnici, a od pet samostavnici, a sklanja se samo jedan, jedna, jedno" (50). Međutim Veber nastavlja dalje kritičkim osvrtom na razumijevanje gramatičke činjenice u hrvatskom u vezi sa sklonidbom brojeva: "O drugih se mněnja odvajaju; jedni hoće da se i ostali sklanjaju, a drugi, da se nesklanjaju, već kad ih treba sklanjati, da se pretvore u samostavničke brojnike: dvojica, trojica, itd. dvoje, troje, itd." (isto). Poslije navedenoga autorskom opaskom "Ostaviv pitanje nerěšeno, prelazim na sklanjanje latinskih brojnikah" (isto) formalno se vraća polaznomu opisu latinskoga.

U Veberovu osvrtu na glavne brojeve u hrvatskom jeziku uočavamo dvije tvrdnje. Prvo, glavne brojeve do četiri smatra pridjevima, a od pet imenicama. U skladu s njegovim gramatikama hrvatskoga jezika, npr. u Slovnici hèrvatskoj za srednja učilišta navodi da se od glavnih brojeva "pèrva četiri smatraju za pridavnike, ter imaju posebnu deklinaciju, a ostali se smatraju za nesklonive samostavnike srednjega spola" (Veber 1871: 50). ${ }^{8}$ Budući da su Temelji ilirskoga i latinskoga jezika (1839) izravna preteča Veberovoj latinskoj slovnici, nalazimo da u njima Mažuranić (1839: 52) također tvrdi da su prva četiri glavna broja pridjevi, ostali su brojevi u nominativu, akuzativu i vokativu imenice, a u drugim padežima pridjevi. Takvo gramatičko pravilo nalazimo i u Mažuranićevoj Slovnici Hèrvatskoj (1859: 54). Drugo, dok je ovdje istaknuto sklanjanje broja jedan, u Skladnji je u dijelu o porabi brojeva pravilo da brojevi "ako stoje bez predloga, sklanjaju se svi i slažu sa svojimi imeni” (Veber 1859: 77). Mažuranić (1839: 52) normira sklonidbu svih glavnih brojeva (ne samo onih od jedan do četiri), a tako i u Slovnici, ${ }^{9}$ gdje ipak u bilješci ističe da "broji pet i dalje pogubiše sve padeže" (Mažuranić 1859: 58). Međutim za Veberov je kritički osvrt u latinskoj slovnici

8 Navedenoj gramatičkoj tvrdnji supostavlja i dijakronijsko objašnjenje: “Opazka. U starijem su se jeziku glavni brojnici, počam od pet, smatrali samo u nom., ak. i vok. za nesklonive samostavnike, a u drugih su se padežih deklinirali kano pridavnici: n. p. pet perah, petih perah, petim perom itd. - Nu buduć da se takovim dekliniranjem glavni brojnici pomèrsuju u rečenih padežih s rednimi, to se za razliku u novijem jeziku, osobito štokavskom, glavni brojnici, počam od pet, dèrže svuda za nesklonive samostavnike, a kad jim treba padeže razlikovati, onda služe s raznimi predlozi; n. p. město: Niti desetimi peri neće neznalica ništa dobra napisati, kaže se: Niti sa deset perah" (Veber 1871: 50-51).

9 Valja pritom naglasiti da Veber (1887: 10) u ocjeni Mažuranićeve Slovnice savjetuje da se ostali hrvatski slovničari "strogo drže ovoga piščeva nauka" jer "zašto da nesklanjanjem brojnikah tromim činimo svoj okretni jezik?" 
“o mněnju drugih", čini se, izravan poticaj bilješka u Temeljima (1839: $52)^{10}$ na osnovi koje Veber komentira nastalu dvojbu i predloženu uporabu brojevnih imenica (samostavničkih brojnika). U sintaksi latinskih padeža (opis akuzativa) Veber objašnjava još jedno važno gramatičko pitanje u vezi s obilježjima sklonidbe imenica (padež i gramatički broj) u sastavnici s glavnim brojem:

Razuměva se pako samo po sebi, buduć da su u nas glavni brojnici od pet počamši samostavnici, da se drugi samostavnik, što s brojnikom dolazi, postavlja u genitiv višebroja, a brojnici do četiri da se sa samostavnikom metju u dvobroj, što kod Latinah nebiva. (183)

Razvidno je da Veber postavlja temelje opisa gramatički složenoj vrsti riječi u hrvatskom jeziku - brojevima.

Sljedeći je primjer izravnoga opisa hrvatskoga gramatičkog pravila, u okviru latinskih odnosnih zamjenica, Veberov metakomentar o zamjenicama tko i što koje se

u nas [...] uzimaju ponajviše kano samostavnici, dolaze ipak i kano pridavnici, kad su bez samostavnika u prednjoj izreci, a u otražnjoj su rěči, na koje se protežu, n. p. tko se naukom bavi, ćuti (on) najveću slast; što tko čeka, to i dočeka. Prema ovim su koji i koje, koji se metju, kad se protežu na rěč ili u prednjoj ili u istoj izreci. (65)

Navedeno se potvrđuje i u Mažuranićevu promišljanju (Temelji, 59) o upitnim zamjenicama tko i što kao pitajućim samostavnim i zamjenici koji (-a, -e) kao pitajućem pridavnom. Takvo objašnjenje upitnih zamjenica navodi Veber u Skladnji (1859: 82) i u Slovnici (1871: 151): "Tko i što jesu samostavnici, te stoje sami, a koji-a -e je pridavnik, te stoji uz samostavnik, bio ovaj izražen ili se razuměvao". U Slovnici (1871: 43) izričito tvrdi u dijelu o odnosnim zamjenicama da se "i odnosna zaimena děle na samostavnička [tko i što] i pridavnička [koji, a, e i što za sva tri spola]". Nastavno na razumijevanje navedenih zamjenica stoji i usporedba pojedinih latinskih i hrvatskih neodređenih zamjenica:

10 U njoj Mažuranić daje opasku da "Serblji (polag g. Stefanovića) i Slavonci (polag g. Berlića) jako rědko dekliniraju d va, tri, č e t i r i, izvan ženskoga spola; ostale pako broje p e t, šest, s e d a m i t. d. nikada; nego ako jim trěba koi broj u genitivu, dat. praep. i instrumentala izreći, onda, razgovarajući se o živućih stvarih, na město dv a, tri, č e ti r i uzimaju: dv o jica, trojica, četveric a ili četvorica, i to samo u mužkom, a dalje: peterica (ili pe t o r i c a ), š esteric a, se d me ri c a i t. d. u mužkom i ženskom spolu [npr. dvojica junakah / peterica ženah, op. a.] [...] U srědnjem pako spolu pri živućih govore i dekliniraju u takvoj sgodi dvoje, troje, četvero, petero it. d.” (Mažuranić 1839: 52). 
[...] koja su sastavljena sa quid, naški što, rabe uvěk kano samostavnici; a koja su sa quod, naški koje, da služe uvěk kano pridavnici; zaimena sastavljena sa quis, služe uvěk i kano samostavnici i kano pridavnici; u nas su kano samostavnici na tko, a pridavnici na koji. (67)

Uz analizirane neposredne primjere u ovaj se model uvjetno mogu ubrojiti i dvije sljedeće Veberove opaske. Prva je od njih bilješka (uz opis latinskoga aorista u dijelu o značenju i porabi vremena u glavnim rečenicama) u kojoj Veber izravno kritizira zaključke drugih gramatičara u vezi s opisom/razumijevanjem gramatičke činjenice u hrvatskom jeziku:

*) Mi i Latini imamo za aorist i perfekt jedan oblik; jer ono što někoji učeni Česi: Šafařik i Šumavski uče, da je: prodah aorist a prodao sam perfekt, neima temelja u sadašnjem našem jeziku; někoč je to valjalo, kano što se vidi iz staroslavenskoga jezik; no sada se je ova razlika posve izgubila. (241)

Ne ulazeći podrobnije u pojašnjenje Veberove tvrdnje, navedenim primjerom u okviru drugoga modela pokazujemo tip izravnoga komentara autora gramatike, koji prelazi okvire gramatičke usporedbe u osnovnome tekstu, a ulazi u metakomentar pripadan jezikoslovnoj raspravi. Drugi je sličan primjer također iz sintaktičkoga dijela gramatike, a tiče se opisa veznoga načina (latinskoga konjunktiva). Donoseći metakomentar u odnosu na hrvatski jezik da se opis pravila za latinski konjunktiv

nemože na naš jezik doslědno protegnuti, jer je naš vezni nešto nesavèršen, jer osim pogodbena dva i odnosna dva neimamo više vremenah; ostala odnošenja izrazuju se u nas koje pokaznim, dodajuć mu razne veznike, koje odnosnim ili pogodbenim s raznimi veznici (259),

Veber završava usporedbu tvrdnjom: “[...] s toga je nauk o latinskom veznom za naške početnike podosta mučan" (isto), što je primjer svojevrsnoga autorova metodičkoga metakomentara.

Navedeni drugi model opisa izvor je Veberovih izravnih gramatičkih promišljanja o određenim gramatičkim kategorijama i pravilima u hrvatskom jeziku. To su ponajprije svojevrsna opća mjesta svojstvena gramatičkomu opisu hrvatskoga jezika (npr. pitanje brojeva kao vrste riječi na morfološkoj osnovi, pojedinih vrsta zamjenica, glagolskih oblika i načina i dr.).

U tim metakomentarima uočava se autorov stav ili jezikoslovno rješenje na razini mogućega gramatičkog opisa, što je usporedivo u Veberovim gramatikama hrvatskoga jezika gdje navodi iste ili slične gramatičke opise i rješenja. Drugim riječima, tamo gdje je latinski gramatički tekst bio najizloženiji ondašnjim kritikama i recenzijama (kako je prethodno navedeno u uvodnom dijelu), takvi su gramatički dijelovi opisa važni s gledišta povijesti 
gramatika hrvatskoga jezika, ali i Veberovih gramatika hrvatskoga jezika. Međutim primjeri dvaju navedenih metakomentara pridruženi ovomu tipu (pripadno jezikoslovnoj i metodičkoj raspravi), unatoč prethodno autorski zadanoj usporednoj metodi, najviše se udaljuju od osnovnoga teksta gramatike latinskoga jezika.

Analizirani primjeri drugoga modela opisa ispušteni su u cijelosti u izdanju gramatike iz 1872. godine, stoga se Veberovo neposredno kritičko i analitičko propitivanje pojedinih gramatičkih pravila hrvatskoga jezika nalazi jedino u prvom izdanju Latinske slovnice.

\subsubsection{Tré́i model opisa}

Treći je model onaj kojim se uz gotovo svako navedeno pravilo koje se odnosi na latinski jezik objašnjava gramatičko pravilo ili jezični ostvaraj u hrvatskom jeziku. Takva su obilježja modela svojstvena opisima koji obuhvaćaju određene veće gramatičke cjeline.

Jedna je od njih tvorba riječi. Naime Veber latinsku tvorbu imenica, pridjeva i glagola (uključujući i kratak osvrt na tvorbu priloga), na temelju dvaju tvorbenih načina izvođenja i slaganja, opisuje u okviru pojedinačnoga morfološkoga opisa navedenih vrsta riječi kao pripadnoga obilježja vrste, ne izdvajajući tvorbu u posebno gramatičko poglavlje. ${ }^{11}$ Budući da je opis imenica i pridjeva strukturiran prema latinskim sufiksima (dočetcima) s definicijom tvorbenoga značenja, Veber gotovo svaki sufiks uspoređuje s pripadnim sufiksom ili tvorbenim obilježjem u hrvatskom jeziku, npr. "Dočetkom or prave se iz prelaznih glagoljah samostavnici mužkoga spola, naznačujući osobu, koja što čini. [...] U našem se jeziku prave dočetkom ač ili telj" (29), ili "Pridavnici na ālis i āris naznačuju svojinu ili svojstvo imena; u našem se jeziku prave dočetkom ski; it" (45). ${ }^{12} \mathrm{Na}$ taj način supostavlja određene primjere hrvatskih sufikasa latinskima, a definicija tvorbenoga značenja pripadna je i hrvatskim sufiksima.

Druga je takva cjelina u morfološkom dijelu poraba prijedloga, koju i sam Veber naziva da je "poněšto zamèršena, pa i značenje različito" te "da se lasnije pogodi, kako ih valja naški prevoditi, metje se ovdě potrebito razjašnjenje" (136) opravdava svoj metodološki postupak kojim svakomu

11 Tvorba je u posebno poglavlje izdvojena u izdanjima iz 1872. (i 1877) godine.

12 Tvorbeni opis i u gramatici 1872. godine djelomice zadržava usporedbe s tvorbom u hrvatskom jeziku, npr.: "1. Tvorkom or prave se $a$ ) iz supina prelaznih glagoljah samostavnici, naznačujući osobu, koja što radi (naški a č ili telj)" (Veber 1872: 105). 
prijedlogu (prema tomu koji padež zahtijeva) i njegovu određenu značenju u latinskom jeziku navodi hrvatski primjer prijedloga, npr.

Ad rabi: a) o vremenu, 1. naznačujuć granicu, dokle što biva; naški: do; n. p. ad sumam senectutem, do kasne starosti. 2. naznačujuć neizvěstno vrěme, kad što biva; naški o, $\boldsymbol{u}$; n. p. ad lucem, o zori; [...], b) o městu: 1 . kad se pita kamo? naški k ili sam dativ; n. p. venio ad te, dolazim k tebi; scribo ad patrem, pišem otcu; 2. kad se pita gdě? (ne ob osobah); naški kod, blizu; n. p. (ad forim, kod, blizu fora.(136) ${ }^{13}$

Izdvoje li se oni latinski prijedlozi koji su usporedno objašnjeni hrvatskim, dobiva se kontrastivni popis i opis latinskih i hrvatskih padežnih značenja prijedloga. Iz takva popisa moguće je izdvojiti metajezični opis hrvatskih padežnih značenja kao svojevrsnu podlogu gramatici hrvatskoga jezika.

Treća je cjelina u morfološkom dijelu, istovjetna načinom opisa prethodnoj cjelini, kontrastivan pristup veznicima zavisnosloženih rečenica koje Veber naziva podredni i "vežu ovisne izreke s glavnom" (151). ${ }^{14}$ Veznici se u tom slučaju kontrastivno opisuju navođenjem značenja ili funkcije polaznoga latinskoga, a ako izostaje značenje, obvezna je sastavnica samo primjer hrvatskoga veznika, npr.

Quia naznačuje pravi uzrok, koji biva ili se je sbio u životu, te potvèrdjuje onaj čin kano istinu; naški, ako uzrok stoji pred činom, komu je uzrok, prevadja se: buduć da, ako za njim: jer. (160)

Četvrta je cjelina u sintaktičkom dijelu gramatike ona o značenju i porabi glagolskih vremena u glavnim i zavisnim (ovisnim) rečenicama, gdje se za svako latinsko glagolsko vrijeme navodi ono koje je u uporabi u hrvatskom jeziku ili kojim se prevodi latinska glagolska konstrukcija, npr. "Sadanje naznačuje čin, koji sada biva, trajao malo ili dugo; naški se uzima uvěk sadanje trajućega" (238) ili "Buduće naznačuje čin, koji se ima tek dogoditi, bilo taki ili kasno; naški se metje ponajviše buduće, no kadšto i sadanje i trajućih i minućih glagoljah" (242). ${ }^{15}$

S obzirom na obilježja gramatičkoga opisa navedenoga poglavlja ovdje

13 Opis je porabe prijedloga u gramatici 1872. god. u sintaktičkom dijelu gramatike, a odnos prema hrvatskomu navodi se samo prijevodom prijedloga, npr. " $A d$ rabi a) o vremenu, 1 . naznačujuć g ranicu, dokle što biva (d o ); n. p. ad sumam senectutem, do kasne starosti [...]" (Veber 1872: 137).

14 Vrste su zavisnih (podrednih) veznika: městni, vrěmenni, pogodbeni, uzročni, dopustni, naměrni, poslědični, prispodobni i upitni.

15 "1. Praesens znači čin a) koji biva, kad pisac piše, trajao malo ili dugo (naški : praesens imperfektivni)"; "8. Futur naznačuje čin, koji se ima tekar dogoditi, bilo taki ili kasno" (Veber 1872: 156, 158). 
naglašavamo dvije činjenice. Prva je od njih u vezi s glagolskim vidom koji nije neposredno kategorijalno obilježje latinskih glagola kakvo je na morfološkoj razini u hrvatskom jeziku, stoga Veber navedeno poglavlje latinske slovnice počinje objašnjenjem glagolske kategorije u hrvatskom na razini svršenih/nesvršenih glagola: "Buduć da se naški glagolji děle na trajuće i minuće, o kojoj razlici neima u latinskom jeziku, osim několiko glagoljah prostih i s predlozi sastavljenih, ni traga, naznačenje je pravilah, po kojih da se latinska vremena naški prevode, dosta mučno" (238) ${ }^{16}$ Naime kontrastivnomu opisu glagolskih vremena potrebno je supostaviti pitanje (ne)svršenih glagola u hrvatskom jeziku u odnosu na latinski. Međutim valja istaknuti da je u Veberovoj Skladnji (1859: 92-100) poglavlje O značenju $i$ porabi vremenah u glavnih izrekah $\mathrm{i}$ temelji se na sintaksi glagolskih vremena i objašnjenju vidskih parametara u okviru rečeničnoga ustrojstva. Iz toga proizlazi druga činjenica koja potvrđuje da je koncepciju opisa glagolskih vremena u latinskom utemeljenu i provedenu u Latinskoj slovnici zadržao i nasljedovao i u Skladnji ${ }^{17} \mathrm{u}$ kojoj se struktura sintaktičkoga opisa u poglavlju uporabe i značenja glagolskih vremena može usporediti s navedenom.

U četvrtu se cjelinu mogu ubrojiti i primjeri iz opisa sintakse glagolskih načina i sintakse padeža ${ }^{18} \mathrm{u}$ latinskom jeziku, ovisno o usporednim obilježjima i naravi gramatičke kategorije $\mathrm{u}$ oba jezika.

U izdanju gramatike 1872. godine najviše je usporednih komentara trećega modela opisa zadržano u sintaktičkim poglavljima gramatike.

Prema cjelinama u navedenom trećem tipu razvidno je da je riječ o dijelovima morfološkoga, a posebice sintaktičkoga gramatičkoga opisa, koje Veber u odnosu na zadanu metodu objašnjenja hrvatskih pravila smatra nužno (i neizostavno) usporedivima, upravo prema naravi gramatičke činjenice o kojoj je riječ.

16 U morfološkom dijelu latinske slovnice jedinu opasku o glagolskom vidu Veber usputno navodi u bilješci: “*) Svaki latinski glagolj može se naški prevesti i trajućim i minućim”, i to s metodičkim ciljem pojašnjenja prijevoda latinskih glagola: "ovdě je postavljen samo jedan, koji se je činio najobičniji, drugi će svaki našinac, ako mu uztreba, lako sam napraviti” (85). Navedena je bilješka i u morfološkom dijelu gramatike iz 1872. god.

17 Isto je tako i u Slovnici hèrvatskoj (1871), ali se o glagolskom vidu raspravlja i na dvjema drugim gramatičkim razinama, morfološkoj i tvorbenoj (usp. Brlobaš 2007: 203-207).

18 Npr.: "U dativ se metje osoba ili stvar, kojoj čin kakovu korist ili štetu nanosi; naški akuzativ s predlogom za" (188). 


\section{ZAKLJUČAK}

Veberov kontrastivan pristup u Latinskoj slovnici 1853. godine, unatoč prvim negativnim metodičkim stručnim ocjenama, ipak opravdava svoju svrhu iz nekoliko razloga:

1. krajnjim je korisnicima olakšano razumijevanje i učenje latinske školske gramatike ne samo time što je metajezik gramatike hrvatski nego i usporednim navođenjem gramatičkih pravila hrvatskoga jezika, što na razini pokušaja približavanja učenja latinskoga i hrvatskoga ipak u konačnici do kraja stoljeća (i dalje) nije zaživjelo, kao ni u metodologiji sastavljanja gramatika latinskoga jezika

2. nastavlja se na niz kontrastivnih gramatika hrvatskoga jezika, između kojih su npr. neposredna preteča ovoj gramatici i Mažuranićevi Temelji ilirskoga i latinskoga jezika (1839)

3. u kontekstu povijesti hrvatskih gramatika pokazuje se da AdoIfo Veber na primjeru opisa drugoga sustava vješto i znalački podastire i obilježja hrvatskoga jezika te se, unatoč tipu školskoga udžbenika, kritički osvrće na opća problemska pitanja, ali i objašnjenja pojedinih kategorijalnih obilježja u gramatici hrvatskoga jezika, što je analizom potvrđeno u drugome modelu gramatičkoga opisa.

Analiza svojevrsnih Veberovih gramatičkih metakomentara o hrvatskom jeziku na primjeru opisa latinskoga jezika prema trima osnovnim tipovima pokazuje i temelje osnovne strukture opisa gramatičkih činjenica u hrvatskom jeziku ili, drugim riječima, nacrte budućih važnih gramatičkih problemskih pitanja i njihovih jezikoslovnih objašnjenja u Veberovim gramatikama hrvatskoga jezika, što su poslije Latinske slovnice ubrzo ostvareni u Skladnji ilirskoga jezika i u Slovnici hèrvatskoj. 


\section{LITERATURA}

Brlobaš, Željka. 2007. Glagolski vid u hrvatskim gramatikama do 20. stoljeća. Zagreb: Institut za hrvatski jezik i jezikoslovlje.

Demo, Šime. 2007. Od Latinske slovnice do Latinske gramatike. "Filologija" 49, 37-49. Jezikoslovne rasprave i članci (F. Kurelac, B. Šulek, V. Pacel, A. V. Tkalčević) [prir. Ivo Pranjković]. 1999. Zagreb: Matica hrvatska.

Mažuranić, Antun. 1839. Temelji ilirskoga i latinskoga jezika za početnike. Zagreb: Tiskom k. pr. nar. ilir. tiskarne Dra. Ljudevita Gaja.

Mažuranić, Antun. 1859. Slovnica Hèrvatska. Za gimnazije i realne škole. Dio I. Rěčoslovje. Zagreb: Troškom spisateljevim. [Pretisak Institut za hrvatski jezik i jezikoslovlje, Zagreb, 2008.].

Pongračić, Franjo. 1869. Opazke k Veberovoj latinskoj slovnici. Izvěstje gimnazije varaždinske koncem školske godine 1869. Varaždin: Tiskarski zavod Platzera i sina. $3-14$.

Pranjković, Ivo. 1993. Adolfo Veber Tkalčević. Zagreb: Zavod za znanost o književnosti Filozofskoga fakulteta Sveučilišta u Zagrebu.

Pranjković, Ivo. 1998. Adolfo Veber Tkalčević kao jezikoslovac (na primjeru definicija u Skladnji ilirskoga jezika). Riječki filološki dani 2: Zbornik radova s međunarodnoga znanstvenog skupa Riječki filološki dani, održanoga u Rijeci od 5. do 7. prosinca 1996. [ur. Marija Turk]. Rijeka: Filozofski fakultet, 1-8.

Pranjković, Ivo. 2005. Adolfo Veber Tkalčević i njegova skladnja. Weber, Adolfo. Skladnja ilirskoga jezika za niže gimnazije. [Faks. pretisak izd.]. Zagreb: Institut za hrvatski jezik i jezikoslovlje, 197-229.

Turoman, Jovan. 1875. Kritika. Slovnica latinska A. Vebera, ocena dra. J. Turomana. Slovnica latinska za male gimnazije napisao Adolfo Veber, kanonik zagrebački. Drugo popravljeno izdanje. U Zagrebu 1872. Letopis Matice srpske 117, 135-171.

Veber (Weber), Adolfo. 1853. Latinska slovnica za nižu gimnaziju. Beč: Troškom c. k. uprave za razprodaju školskih knjigah kod sv. Anne u Ivanovoj ulici.

Veber (Weber), Adolfo. 1865. Latinska slovnica za nižu gimnaziju. Beč: Troškom c. k. prodaonice školskih knjigah. Tiskom $\mathrm{C}$. kr. dvorske i dèržavne tiskarne.

Veber (Weber), Tkalčević, Adolfo. 1859. Skladnja ilirskoga jezika za niže gimnazije. Beč: U c. k. nakladi školskih knjigah. [Faks. pretisak izd., Institut za hrvatski jezik i jezikoslovlje, Zagreb, 2005.].

Veber, Adolfo. 1871. Slovnica hèrvatska za srednja učilišta. Zagreb: Troškom spisateljevim.

Veber, Adolfo. 1872. Slovnica latinska za male gimnazije. Drugo popravljeno izdanje. Zagreb: Troškom spisateljevim, a slovi Lav. Hartmána i družbe.

Veber, Adolfo. 1877. Slovnica latinska za male gimnazije. Treće izdanje. Zagreb: Dionička tiskara. Troškom spisateljevim, a slovi dioničke tiskarne.

Veber, Adolfo. 1885. Životopis Adolfa Vebera. Djela Adolfa Vebera zagrebačkoga kanonika, sv. 1. Zagreb: Tiskom Dioničke tiskare, 1-40. 
Veber, Adolfo. 1887. Slovnica hrvatska Antuna Mažuranića. [1859]. Djela Adolfa Vebera zagrebačkoga kanonika, sv. 3. Zagreb: Tiskom Dioničke tiskare, 5-20.

Veber, Adolfo. 1889. Kako treba pisati latinske slovnice za gimnaziju. [1876.] Djela Adolfa Vebera zagrebačkoga kanonika, sv. 5. Zagreb: Tiskom Dioničke tiskare, 121-156.

\section{SUMMARY}

\section{VEBER'S GRAMMATICAL REFLECTIONS ON THE CROATIAN LANGUAGE IN LATINSKA SLOVNICA ZA NIŽU GIMNAZIJU (1853)}

In particular descriptions in his Latinska slovnica za nižu gimnaziju (Vienna 1853), Adolfo Veber Tkalčević also compares grammatical rules typical of the Croatian language. This paper analyses three basic models of grammatical description through which Veber displays his grammatical reflections on the Croatian language in the basic text of his Latin school grammar. The first model is a comparative description of similarities or differences between grammatical rules in both languages. The second model is one in which Veber also discusses grammatical problems typical of the Croatian language. In the third model, alongside nearly every Latin grammatical rule, Veber explains grammatical rules in the Croatian language.

Key words: Latinska slovnica za nižu gimnaziju (1853), Adolfo Veber Tkalčević, Croatian grammatical rules 